University of Nebraska - Lincoln

DigitalCommons@University of Nebraska - Lincoln

2020

\title{
Size and Density of Upside-Down Jellyfish, Cassiopea sp., and Their Impact on Benthic Fluxes in a Caribbean Lagoon
}

Chester B. Zarnoch

CUNY Bernard M Baruch College, Chester.Zarnoch@baruch.cuny.edu

Noshin Hossain

CUNY Bernard M Baruch College

Erika Fusco

CUNY Bernard M Baruch College

Mary Alldred

SUNY Plattsburgh

Timothy J. Hoellein

Loyola University Chicago

See next page for additional authors

Follow this and additional works at: https://digitalcommons.unl.edu/global

Part of the Anthropology Commons, Aquaculture and Fisheries Commons, Biodiversity Commons, Biological and Chemical Physics Commons, Ecology and Evolutionary Biology Commons, Geography Commons, International and Area Studies Commons, Marine Biology Commons, and the Oceanography Commons

Zarnoch, Chester B.; Hossain, Noshin; Fusco, Erika; Alldred, Mary; Hoellein, Timothy J.; and Perdikaris, Sophia, "Size and Density of Upside-Down Jellyfish, Cassiopea sp., and Their Impact on Benthic Fluxes in a Caribbean Lagoon" (2020). Global Studies Papers \& Publications. 12.

https://digitalcommons.unl.edu/global/12

This Article is brought to you for free and open access by the School of Global Integrative Studies at DigitalCommons@University of Nebraska - Lincoln. It has been accepted for inclusion in Global Studies Papers \& Publications by an authorized administrator of DigitalCommons@University of Nebraska - Lincoln. 
Authors

Chester B. Zarnoch, Noshin Hossain, Erika Fusco, Mary Alldred, Timothy J. Hoellein, and Sophia Perdikaris 
Published in Marine Environmental Research (2020) 154: 104845. doi: 10.1016/j.marenvres.2019.104845

Copyright 2020, Elsevier. Used by permission.

\author{
Size and Density of Upside-Down Jellyfish, Cassiopea sp., and Their Impact on \\ Benthic Fluxes in a Caribbean Lagoon \\ Chester B. Zarnoch, Noshin Hossain, Erika Fusco, Mary Alldred, Timothy J. Hoellein, \\ and Sophia Perdikaris
}

\begin{abstract}
Anthropogenic disturbances may be increasing jellyfish populations globally. Epibenthic jellyfish are ideal organisms for studying this phenomenon due to their sessile lifestyle, broad geographic distribution, and prevalence in near-shore coastal environments. There are few studies, however, that have documented epibenthic jellyfish abundance and measured their impact on ecological processes in tropical ecosystems. In this study, the density and size of the upside-down jellyfish (Cassiopea spp.) were measured in Codrington Lagoon, Barbuda. A sediment core incubation study, with and without Cassiopea, also was performed to determine their impact on benthic oxygen and nutrient fluxes. Densities of Cassiopea were 24-168 $\mathrm{m}^{-2}$, among the highest reported values in the literature. Under illuminated conditions, Cassiopea increased oxygen production $>300 \%$ compared to sediment alone, and they changed sediments from net heterotrophy to net autotrophy. Cassiopea increased benthic ammonium uptake, but reduced nitrate uptake, suggesting they can significantly alter nitrogen cycling. Future studies should quantify the abundance of Cassiopea and measure their impacts on ecosystem processes, in order to further determine how anthropogenic-related changes may be altering the function of tropical coastal ecosystems.
\end{abstract}

Keywords: Jellyfish, Nitrogen, Caribbean, Eutrophication, Biogeochemical cycling, Flux, Respiration, Sediment chemistry

\section{Introduction}

Globally, there have been increasing reports of massive jellyfish blooms (Purcell et al., 2007). These blooms have been attributed to several factors, including overfishing, climate change, eutrophication, translocation, and marine construction and development (Purcell et al., 2007; Dong et al., 2010; Duarte et al., 2013). Long-term data on jellyfish abundance is lacking, thus making it difficult to identify trends and relate it to changes in the environment (Condon et al., 2013). However, analyses of anecdotal data suggest that jellyfish populations have been increasing since the 1950s (Brotz et al., 2012). Regardless of the causes, changes in the relative proportion of jellyfish within marine communities may have important consequences for ecosystem function, yet these consequences have rarely been documented.

The upside-down jellyfish Cassiopea spp. (Scyphozoa, Rhizostomidae) are epibenthic organisms that harbor photosynthetic endosymbionts. They are commonly found in ecologically- and economically important habitats, such as around coral reefs, and within seagrass beds and mangrove-dominated lagoons (Ohdera et al., 2018). Cassiopea geographic ranges have increased, they may be increasing in abundance in coastal ecosystems due to anthropogenic disturbances (Stoner et al., 2011), and may act as bio-invaders (Keable and Ahyong, 2016; Morandini et al., 2017). Yet, few studies have quantified the abundance of Cassiopea and their ecological impacts. Densities up to $7 \mathrm{~m}^{-2}$ have been described in the Bahamas (Stoner et al., 2011) and densities as high as $31 \mathrm{~m}^{-2}$ and $42 \mathrm{~m}^{-2}$ were found in the Red Sea (Niggl and Wild, 2010) and Mexico's Nichupte Lagoon System (Collado Vides et al., 1998), respectively. Stoner et al. (2011) suggested that Cassiopea density and size may be related to nutrient availability, as Cassiopea and their algal symbionts are generally nutrient limited. Anthropogenic disturbances that promote nutrient loading may thereby enhance Cassiopea populations (Arai, 2001; Stoner et al., 2011). High nutrient availability can increase symbiont density (Stoner et al., 2016), although it is not clear if this is due to increased water column nutrients or through increased secondary production (i.e. increased jellyfish prey). Cassiopea tissues also can assimilate nitrogen directly from the water column to support nitrogen demands (Freeman et al., 2016).
High densities of Cassiopea alter benthic invertebrate community composition in seagrass beds (Stoner et al., 2014a) and reduce relative coverage and shoot density of seagrass (Stoner et al., 2014b). The pumping motion of the bell on the sediment promotes exchange between porewater and the water column (Jantzen et al., 2010); in addition, direct assimilation of dissolved inorganic nitrogen by Cassiopea couples benthic and pelagic environments (Jantzen et al., 2010; Welsh et al., 2009). Blooms and subsequent decay of jellyfish populations can lead to major changes in biogeochemical cycles in coastal ecosystems, as jellyfish can mediate pathways for assimilation and recycling of carbon, nitrogen, and phosphorous (West et al., 2009; Chelsky et al., 2016).

The aims of this study were to quantify the density and size distribution of Cassiopea populations within a portion of Codrington Lagoon (Barbuda, West Indies) that is affected by anthropogenic nutrients, as well as to determine impacts of Cassiopea on benthic fluxes. Although local citizens reported increases in the prevalence of Cassiopea in recent years (Ruttenberg et al., 2018), no previous studies have collected quantitative measurements to document abundance or other changes through time. We expected oxygen demand and nitrogen effluxes would increase in the presence of Cassiopea under dark conditions. In contrast, light conditions would promote oxygen production and nitrogen assimilation. The insights from this study were then used to suggest potential management practices.

Zarnoch: Baruch College and City University of New York, New York, New York, USA, and Corresponding author, Chester.Zarnoch@baruch.cuny.edu

Hossain, Fusco: Baruch College and City University of New York, New York, New York, USA

Alldred: SUNY Plattsburgh, Plattsburgh, New York, USA

Hoellein: Loyola University Chicago, Chicago, Illinois, USA

Perdikaris: University of Nebraska-Lincoln, Lincoln, Nebraska, USA

Received Sep 11, 2019; Received in revised form Nov 12, 2019; Accepted Nov 20, 2019 


\section{Materials and methods}

\subsection{Study site}

The study was performed on the island of Barbuda, which is part of the nation of Antigua and Barbuda, located in the Lesser Antilles area of the Caribbean (Figure 1). Barbuda $\left(161 \mathrm{~km}^{2}\right)$ is a sparsely populated, low-lying, coral island with only one town (Codrington); the rest of the island remains largely undeveloped (Figure 1). Codrington had a population of 1800 prior to Hurricane Irma in 2017, but was devastated by the hurricane and has had much fewer residents since then (Boger et al., 2016). Codrington Lagoon ( $18 \mathrm{~km}^{2}$; Figure 1) is located on the west side of the island and it supports commercial and subsistence fishing, as well as tourism (Ruttenberg et al., 2018). Soils on Barbuda are highly permeable and shallow with groundwater less than $1.5 \mathrm{~m}$ from the soil surface. Barbuda has no centralized sewage treatment system and most residences have only septic systems or pit latrines (US Army Corps of Engineers, 2004). Therefore, wastewater likely enters groundwater and may impact drinking water supplies; for example, coliform bacteria have been found in groundwater wells throughout Barbuda (Boger et al., 2014).

\subsection{Cassiopea survey}

Cassiopea populations were sampled during February

2014 in a section of Codrington Lagoon locally known as Pearl Harbor. It is adjacent to the northwest portion of the town of Codrington. Three sites within Pearl Harbor were sampled, including one site at the mouth of a creek where commercial fishermen keep moorings for their boats (Site 1), and two sites adjacent to mangrove islands that were further from the creek (Sites 2 and 3; Figure 1). The sites were located $>20 \mathrm{~m}$ apart, water depth was $<1 \mathrm{~m}$, and the tide was ebbing during sample collection. Discussions with local fishermen and naturalists suggested that Site 1 would be most disturbed due to its proximity to the commercial activity in the creek. At each site, we randomly tossed a $0.25 \mathrm{~m}^{2}$ quadrat six times and counted the number of individuals within each quadrat. After completing the density measurements, 25-30 Cassiopea were randomly selected at each site, and the bell diameter $(\mathrm{cm})$ was measured. The mean densities and bell diameters were used to estimate benthic coverage $(\%)$ for each site as this was not directly measured in the field (Niggl and Wild, 2010). Mean bell diameter (cm) was converted to $\mathrm{m}^{2}$ and then multiplied by the mean density $\left(\right.$ No. $\left.\mathrm{m}^{-2}\right)$. Salinity in Pearl Harbor was measured with a refractometer, and a Hach ${ }^{\circledR} \mathrm{HQ} 30 \mathrm{~d}$ luminescent dissolved oxygen probe (Loveland, Colorado, USA) was used to measure temperature and oxygen. Leaf fragments $(n=10)$ were collected from seagrass (Thalassia testudinum) beds adjacent to the three study sites in Pearl Harbor. The fragments were dried at $60^{\circ} \mathrm{C}$, ground into a powder, and measured on a PerkinElmer 2400 Series II CHN analyzer (PerkinElmer Life and Analytical Sciences, Shelton, Connecticut, USA; Zarnoch et al., 2017). The \% carbon and nitrogen were used as

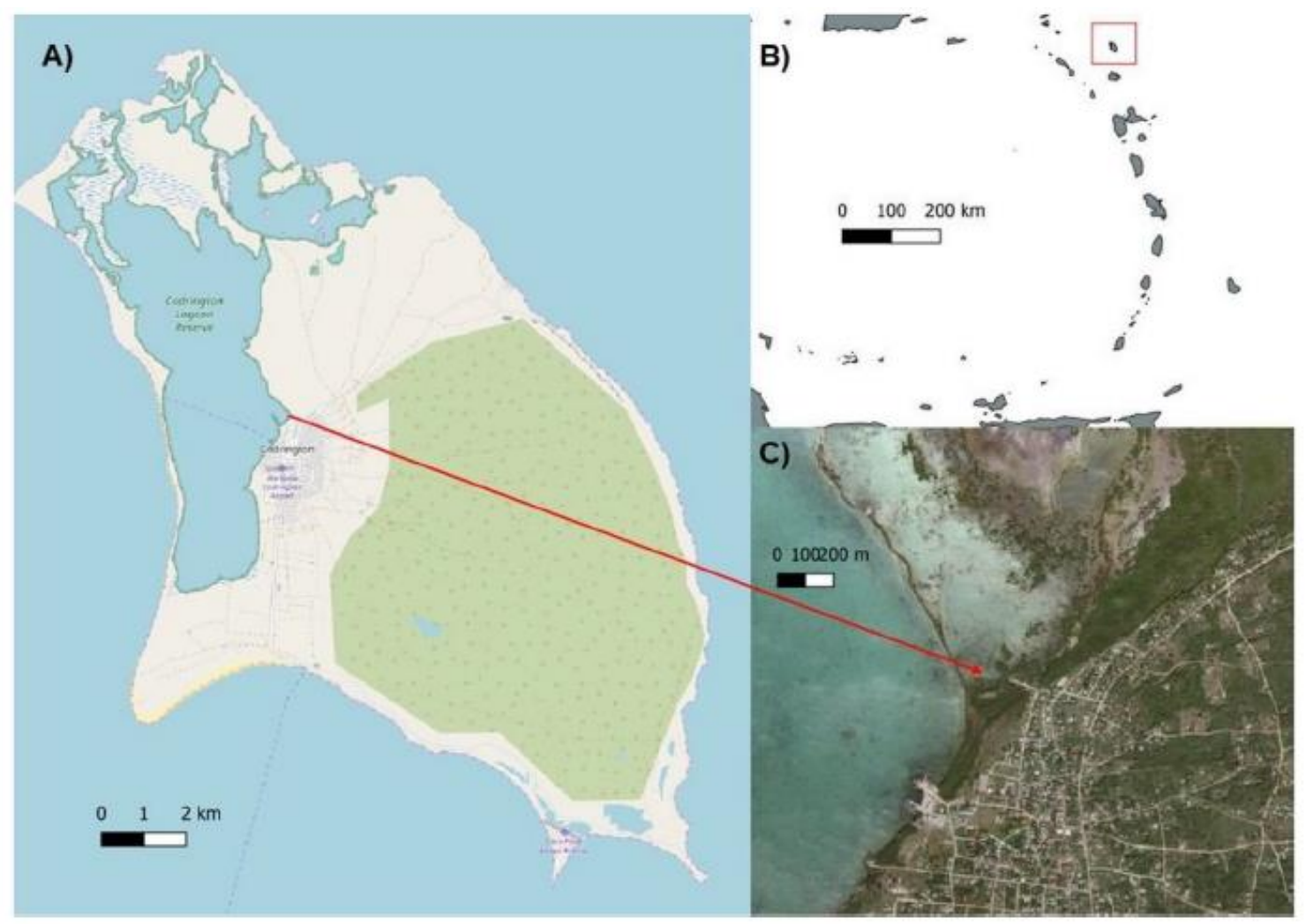

Figure 1. A map of the study site in Codrington Lagoon in Barbuda (A), a part of Antigua and Barbuda in the Caribbean's Lesser Antilles (B; Barbuda is in the box). The Cassiopea were surveyed near the mangrove islands in an area of the lagoon called Pearl Harbor (C). Barbuda has only one town (Codrington) and the remainder of the island is largely undeveloped. 
a proxy for nutrient loading assuming an enriched site would have high \% nitrogen (Stoner et al., 2011; Duarte, 1990).

\subsection{Benthic fluxes}

Sediment cores (acrylic, $25 \mathrm{~cm}$ length $\times 7.6 \mathrm{~cm}$ width) were collected at Site 3 in Pearl Harbor using a coring device with a one-way valve designed to reduce disturbance of the sedimentwater interface (Gardner et al., 2006). The cores were inserted into the sediment to a depth of $\sim 12 \mathrm{~cm}$ and had a volume of $\sim 620$ $\mathrm{mL}$ of overlying site water. Three of the sediment cores collected included a single Cassiopea ( $\sim \mathrm{cm}$ bell diameter) and three of the cores included sediment only. All core samples were taken within 3-5 m of each other. One additional core was collected with only site water to serve as a water column blank (total of 7 cores). Three $20 \mathrm{~L}$ carboys of site water were collected from Pearl Harbor for use in static core incubations and for determining ambient ammonium $\left(\mathrm{NH}_{4}^{+}\right)$, nitrate $\left(\mathrm{NO}_{3}^{-}\right)$, and soluble reactive phosphorous (SRP). The sediment cores and site water were placed in dark coolers and brought back $(<1 \mathrm{~h}$ travel time) to the Barbuda Research Complex to perform benthic flux incubations. Approximately $90 \%$ of the overlying water within each core was carefully removed with a $60 \mathrm{~mL}$ plastic syringe and replaced with new site water. Each core was submerged in site water within a $19 \mathrm{~L}$ container and carefully fitted with a gas-tight lid with no head space or gas bubbles in the cores. Each core had a $2.5 \mathrm{~cm}$ magnetic stirrer that was rotated by an external magnet. Cores were stirred slowly to prevent $\mathrm{O}_{2}$ stratification, sediment resuspension, and disturbance to Cassiopea. Light and dark incubations were performed under in situ temperature conditions for $\sim 2.8 \mathrm{~h}$. Light incubations were performed under ambient light at mid-day and then dark incubations were performed, with the same cores, in an enclosed black container. The overlying water $(\sim 90 \%)$ in each core was carefully removed and replaced with new site water in between the light and dark incubation. Net flux rates were calculated as the average of the light and dark flux rates (Eyre and Ferguson, 2005).

Samples were collected at the beginning and end of each incubation period for measuring gas and nutrient concentrations. Nutrient samples were withdrawn from the cores with a plastic syringe and filtered $(0.2 \mu \mathrm{m}$ nylon syringe filters, Thermo Scientific, Rockwood, Tennessee, USA) into three $20 \mathrm{~mL}$ scintillation vials and frozen at $-20^{\circ} \mathrm{C}$ until measurement of $\mathrm{NH}_{4}^{+}, \mathrm{NO}_{3}^{-}$, and SRP. Water samples from the cores were also transferred into triplicate $12 \mathrm{~mL}$ exetainer vials (Labco Ltd., Lampeter, United Kingdom). Each vial was filled slowly from the bottom and allowed to overflow for several volumes before adding $200 \mu \mathrm{L}$ of $50 \%$ zinc chloride (McCarthy et al., 2007). The vials were capped ensuring no air in the headspace and stored underwater at 4 ${ }^{\circ} \mathrm{C}$ until measurement of dissolved gases. Dissolved inorganic nutrients were measured on an Autoanalyzer III (Seal Analytical, Inc., Mequon, Wisconsin, USA) using the phenol hypochlorite technique for $\mathrm{NH}_{4}^{+}$(Solorzano, 1969), the antimonyl tartrate method for SRP (Murphy and Riley, 1962), and the cadmium reduction method for $\mathrm{NO}_{3}^{-}$(APHA, 1998). Dissolved inorganic nitrogen (DIN) fluxes were calculated as the sum of the $\mathrm{NH}_{4}^{+}$and $\mathrm{NO}_{3}^{-}$fluxes. Concentrations of dissolved $\mathrm{O}_{2}$, was determined with membrane inlet mass spectrometry (MIMS; Bay Instruments, Easton, Maryland, USA; Kana et al., 1994). Standards consisted of artificial seawater maintained at constant temperature $\left(28{ }^{\circ} \mathrm{C}\right.$; Circulating Bath, VWR International, Radnor, Pennsylvania, USA), equilibrated to atmospheric gases by stirring at low speed (Lab Egg RW11 Basic, IKA Works, Inc., Wilmington, North Carolina, USA). Samples were corrected for instrument drift with standard water throughout the run. Nutrient and $\mathrm{O}_{2}$ fluxes were calculated as the final concentration minus the initial concentration of the incubation and were adjusted for surface area of the core, incubation time, and core water volume (flux units $1 / 4 \mu \mathrm{mol}$ element $\mathrm{m}^{-2} \mathrm{~h}^{-1}$; Eyre et al., 2013). Each flux was also corrected with the flux determined from the blank (water column) core. A negative value for nutrient fluxes indicated uptake by sediment or sediment and jellyfish, and a positive value indicated a flux to the water column. The detection limit of the fluxes (i.e. flux near zero) were assumed to be a flux where the standard error did not overlap with zero (Hoellein et al., 2015). Gross benthic primary production was determined from each core as the difference between light $\mathrm{O}_{2}$ fluxes (net production) and dark $\mathrm{O}_{2}$ fluxes (total respiration; Eyre et al., 2013). The overall effect of Cassiopea on benthic fluxes in Pearl Harbor was estimated using the mean fluxes with Cassiopea and mean benthic coverage $(16.8 \%)$ and compared to the sediment only fluxes. For example, the flux with Cassiopea was multiplied by 0.168 (i.e. the proportion of the benthos covered by Cassiopea per $\mathrm{m}^{2}$ ) and added to the flux of the sediment alone multiplied by 0.832 (i.e. the proportion of the benthos without Cassiopea per $\mathrm{m}^{2}$ ). These calculations were performed for nutrient and $\mathrm{O}_{2}$ fluxes under light and dark conditions. A daily flux was estimated using the total hours of light $(13 \mathrm{~h})$ and dark $(11 \mathrm{~h})$ in Barbuda at the time of sampling.

\subsection{Sediment characteristics}

Upon completing the core incubations, the Cassiopea were removed, and seawater was drained from each core. Triplicate $25 \mathrm{~cm}^{3}$ sediment samples were removed from the surface $(0-3 \mathrm{~cm})$ of each core and frozen at $-20^{\circ} \mathrm{C}$ until processed in the laboratory. Sediment samples were defrosted and homogenized to determine organic matter content and sediment chlorophyll- $a$. Sediment organic matter (\%) was determined by drying triplicate subsamples at $60^{\circ} \mathrm{C}$ for $>48 \mathrm{~h}$ to determine the dry weight and then ashing the samples at 500 ${ }^{\circ} \mathrm{C}$ (Benfield, 2006). Sediment porosity was calculated following Berner (1971) after having determined the mass of water in the sample, density of the sediment, and density of the seawater. Triplicate $5 \mathrm{~cm}^{3}$ subsamples were treated with acetone and extracted overnight under dark conditions at $4{ }^{\circ} \mathrm{C}$. Chlorophyll- $a$ was determined spectrophotometrically following Parsons et al. (1984). The extracted sediment was then dried at $60{ }^{\circ} \mathrm{C}$ for $>48 \mathrm{~h}$ to determine the dry weight, and chlorophyll- $a$ was calculated as $\mu \mathrm{g} \mathrm{g}^{-1}$ dry sediment.

\subsection{Statistics}

Differences in density and bell diameter of Cassiopea were examined among sites with a one-way ANOVA. A Tukey post hoc test was used to determine differences among sites. The sediment characteristics of the sediment alone, and sediment + Cassiopea treatments, from the core incubations were compared with $t$-tests. Differences among sites and between treatments should be interpreted cautiously given the low sample size and limited spatial scope of the study. All statistical analyses were performed in SigmaPlot 11 (Systat Inc., Chicago, Illinois). The data are presented as mean \pm standard error (SE).

\section{Results}

3.1. Cassiopea survey and water quality characteristics

Cassiopea densities ranged from 24 to 168 individuals $\mathrm{m}^{-2}$ at our three study sites. The Cassiopea located near the mangrove islands (sites 2 and 3 ) had a mean density of $\sim 100$ 

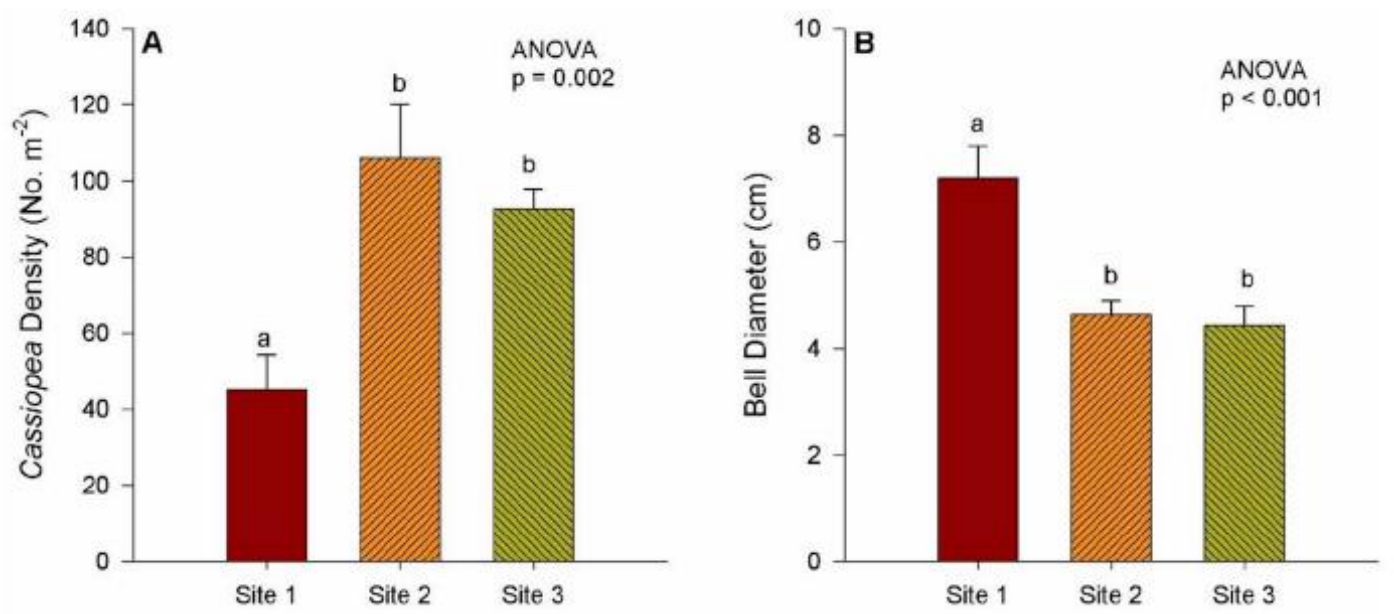

Figure 2. Density (A; No. $\mathrm{m}^{-2} ; n=6$ site $\left.^{-1}\right)$ and bell diameter (B; $\mathrm{cm} ; n=25-30$ site $\left.^{-1}\right)$ of Cassiopea at three sites in Codrington Lagoon, Barbuda.

$\mathrm{m}^{-2}( \pm 7.4)$ which was more than double the density at site 1 $\left(45 \mathrm{~m}^{-2} \pm 8.8\right.$; ANOVA; $F=10.1 ; p=0.002$; Figure 2A). Although site 1 had a lower mean density, the Cassiopea had a $37 \%$ larger bell diameter $(7.2 \mathrm{~cm} \pm 0.6)$ compared to the other two sites (4.5 $\mathrm{cm} \pm 0.2$; ANOVA; $F=13.13 ; p<0.001$; Figure 2B). The calculated benthic coverage was similar across all sites with values of $18.4 \%, 17.8 \%$, and $14.3 \%$ for sites 1,2 , and 3 respectively.

The water column nutrient concentrations in Pearl Harbor were $8.18 \mu \mathrm{mol} \mathrm{L}^{-1}( \pm 0.46)$ for $\mathrm{NH}_{4}^{+}, 0.37 \mu \mathrm{mol} \mathrm{L}^{-1}( \pm 0.06)$ for $\mathrm{NO}_{3}^{-}$, and SRP was $0.07 \mu \mathrm{mol} \mathrm{L}-1( \pm 0.03)$. Water column chlorophyll- $a$ was low $\left(0.58 \mu \mathrm{g} \mathrm{L}^{-1} \pm 0.03\right)$. The temperature was $28^{\circ} \mathrm{C}$, and salinity was 38 . The mean nutrient content of Thalassia testudinum in Pearl Harbor was $31.7( \pm 1.1)$ for \% carbon and $1.5( \pm 0.1)$ for $\%$ nitrogen.

\subsection{Benthic fluxes}

Net oxygen fluxes showed a similar temporal pattern for both sediment and sediment pCassiopea treatments, with $\mathrm{O}_{2}$ production occurring under light conditions and net uptake occurring under dark conditions (Figure 3A). The magnitude of the fluxes, however, were different between the treatments. In cores containing Cassiopea, net $\mathrm{O}_{2}$ production was over $300 \%$ higher under light conditions, and net uptake was $92 \%$ higher under dark conditions, relative to cores containing only sediment. The magnitude of difference between the light and dark fluxes resulted in the sediment + Cassiopea treatment having net production, and the sediment alone had net uptake (Figure 3A). Gross benthic primary production was 3.8 fold higher in the sediment + Cassiopea treatment (Figure 3B).

There were no significant fluxes of DIN in the sediment treatment, but uptake of DIN was evident in the sediment pCassiopea (Figure 4A). Patterns of $\mathrm{NH}_{4}^{+}$(Figure 4B) and $\mathrm{NO}_{3}^{-}$ (Figure 4C) fluxes differed between treatments. Ammonium fluxes in cores containing only sediment were not significantly different from zero in both the light and dark treatments. In contrast, we observed net uptake of $\mathrm{NH}_{4}^{+}$in the sediment + Cassiopea cores under both light and dark conditions, with dark uptake over $230 \%$ greater than light uptake. Nitrate fluxes were near zero in both treatments under light conditions. Under dark conditions, both treatments had an uptake of $\mathrm{NO}_{3}^{-}$, with uptake $>500 \%$ greater in the sediment-alone treatment. The magnitude of flux was much higher for $\mathrm{NH}_{4}^{+}$ than of $\mathrm{NO}_{3}^{-}$. The cores containing both sediment and Cassiopea acted as a net sink for $\mathrm{NH}_{4}^{+}$, while cores with only sediment provided a comparatively smaller net sink for $\mathrm{NO}_{3}^{-}$. There were no net fluxes of SRP under light conditions, but net uptake under dark conditions, resulting in both treatments providing a small net sink for SRP (Figure 4D).

The overall effect of Cassiopea on benthic fluxes given their benthic coverage (Table 1) was largely consistent with the pattern observed for net fluxes. The DIN fluxes showed less release of DIN to the water column under light conditions in the Cassiopea treatment while dark conditions resulted in
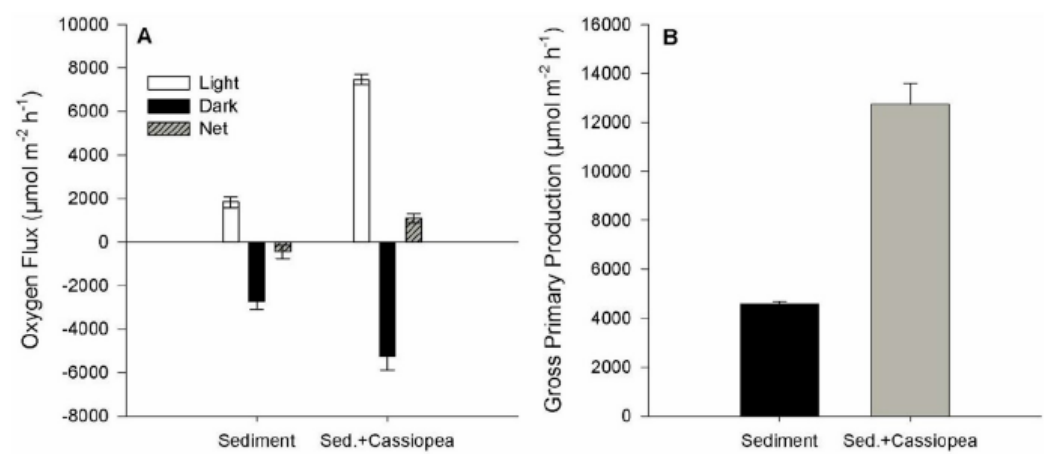

Figure 3. The oxygen flux (A) and gross benthic primary production (B) from sediment core incubations with treatments of sediment or sediment (Sed.) and Cassiopea. Incubations were performed under light and dark conditions. 

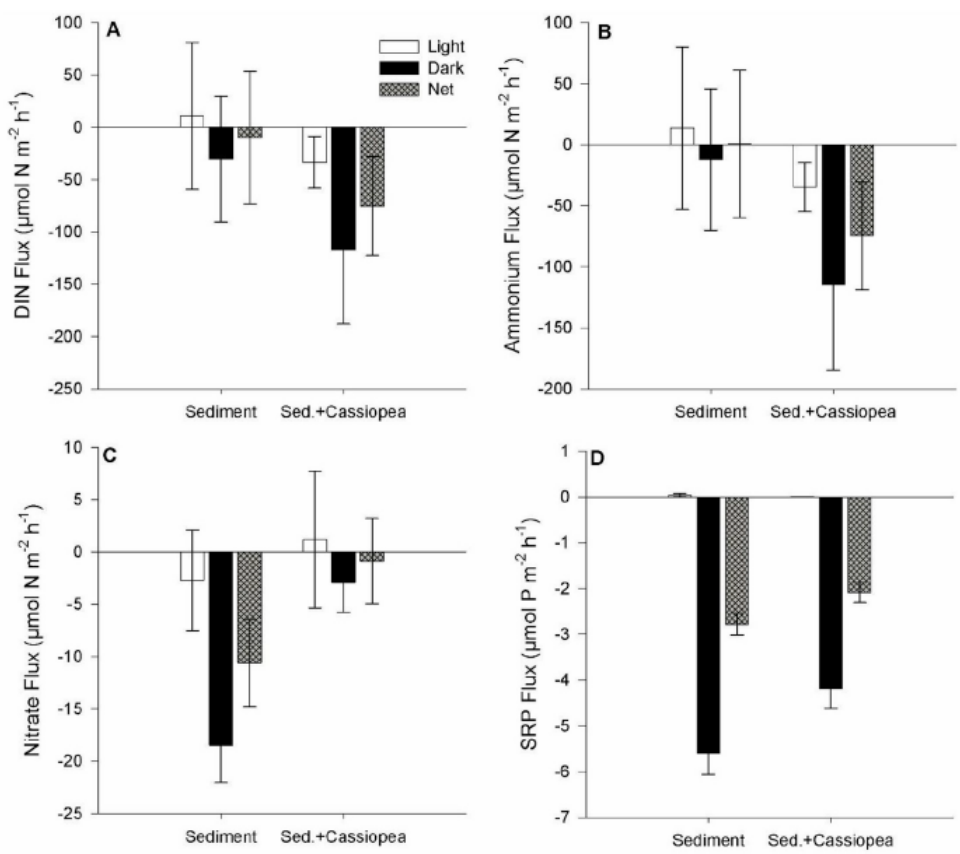

Figure 4. Benthic fluxes of dissolved inorganic nitrogen (DIN; A), ammonium (B), nitrate (C), and soluble reactive phosphorous (SRP; D) from sediment core incubations with treatments of sediment or sediment (Sed.) and Cassiopea. Incubations were performed under light and dark conditions. Net flux was calculated as the average of light and dark fluxes.

Table 1

The calculated benthic fluxes of the sediment alone and fluxes with mean benthic coverage of Cassiopea (16.8\%). The units for the light and dark fluxes are $\mu \mathrm{mol} \mathrm{m}^{-2} \mathrm{~h}^{-1}$ and units for daily fluxes are $\mu \mathrm{mol} \mathrm{m} \mathrm{m}^{-2}$ day $^{-1}$.

\begin{tabular}{lll}
\hline Flux & Sediment & Sediment + Cassiopea \\
\hline Dissolved & Inorganic Nitrogen & \\
Light & 10.7 & 3.3 \\
Dark & -30.6 & -45.2 \\
Daily & -197.2 & -454.6 \\
Ammonium & & \\
Light & 13.4 & 5.3 \\
Dark & -12.1 & -29.3 \\
Daily & 41.7 & -253.1 \\
Nitrate & & \\
Light & -2.7 & -2.1 \\
Dark & -18.5 & -15.9 \\
Daily & -238.8 & -201.5 \\
SRP & & \\
Light & 0.03 & 0.03 \\
Dark & -5.6 & -5.4 \\
Daily & -61.1 & -58.6 \\
Oxygen & & \\
Light & 1828.7 & 2776.3 \\
Dark & -2739.2 & $3164.3-$ \\
Daily & -6358.4 & 1284.3 \\
\hline
\end{tabular}

greater than 2-fold uptake of DIN. This pattern was largely due to the $\mathrm{NH}_{4}^{+}$fluxes which indicated that the sediment alone was a source of $\mathrm{NH}_{4}^{+}$while the Cassiopea treatment was a sink for $\mathrm{NH}_{4}^{+}$. The $\mathrm{NO}_{3}^{-}$and SRP fluxes were similar for both the sediment and the sediment with Cassiopea treatments. There was greater $\mathrm{O}_{2}$ production under light conditions and greater $\mathrm{O}_{2}$ uptake under dark conditions in the Cassiopea treatment as compared to sediment alone. The daily $\mathrm{O}_{2}$ flux indicated that the sediment alone was heterotrophic while the Cassiopea treatment was autotrophic.

\subsection{Sediment core characteristics}

Sediment chlorophyll- $a$ in the sediment + Cassiopea treatments $\left(12.6 \mu \mathrm{g} \mathrm{g}^{-1} \pm 2.0\right)$ was twice as high as the sediment
Table 2

Mean densities and bell diameter of Cassiopea spp. reported in the literature. A range in reported density or bell diameter is given when means were not reported. $\mathrm{N} / \mathrm{A}=$ data not available.

\begin{tabular}{|c|c|c|c|c|}
\hline Location & $\begin{array}{l}\text { Density } \\
\left(\text { No. } \mathrm{m}^{-2}\right)\end{array}$ & $\begin{array}{l}\text { Bell } \\
\text { Diameter } \\
(\mathrm{cm})\end{array}$ & $\begin{array}{l}\text { Calculated } \\
\text { Benthic } \\
\text { Coverage (\%) }\end{array}$ & Study \\
\hline $\begin{array}{c}\text { Codrington, } \\
\text { Barbuda }\end{array}$ & & & & This Study \\
\hline Site 1 & 45.3 & 7.2 & 18.4 & \\
\hline Site 2 & 106.0 & 4.6 & 17.8 & \\
\hline Site 3 & 92.7 & 4.4 & 14.3 & \\
\hline $\begin{array}{l}\text { Abaco Island, } \\
\text { Bahamas } \\
\text { (multiple sites) }\end{array}$ & $0-6.9$ & $\mathrm{~N} / \mathrm{A}$ & $\mathrm{N} / \mathrm{A}$ & $\begin{array}{l}\text { Stoner et al. } \\
(2011)\end{array}$ \\
\hline & 6.9 & 12.4 & 8.3 & \\
\hline $\begin{array}{c}\text { Abaco Island, } \\
\text { Bahamas } \\
\text { Naturally } \\
\text { Occurring }\end{array}$ & & & & $\begin{array}{l}\text { Stoner et al. } \\
(2014 a, b)\end{array}$ \\
\hline $\begin{array}{l}\text { Experimental } \\
\text { Manipulation }\end{array}$ & $<2$ & $\mathrm{~N} / \mathrm{A}$ & & \\
\hline & 10 & $7-10$ & - & \\
\hline Aqaba, Jordan & & & & Niggl \& \\
\hline Reef & 1.6 & 10.3 & & Wild (2010) \\
\hline Transition Zone & 7.9 & 13.1 & & \\
\hline $\begin{array}{l}\text { Seagrass } \\
\text { Meadow }\end{array}$ & 0.4 & 8.3 & & \\
\hline Sand Flat & 1.3 & 13.5 & & \\
\hline $\begin{array}{l}\text { Nichupte Lagoon } \\
\text { System, Mexico }\end{array}$ & 42 & $\mathrm{~N} / \mathrm{A}$ & & $\begin{array}{l}\text { Collado } \\
\text { Vides et al. } \\
(1998)\end{array}$ \\
\hline
\end{tabular}

treatment $\left(5.8 \mu \mathrm{g} \mathrm{g}^{-1} \pm 2.3\right),(t=-2.2 ; \mathrm{df}=4 ; p=0.09)$. There were no statistically significant differences in sediment organic matter $(t=-3.1 ; \mathrm{df}=4 ; p=0.37)$ or porosity $(t=-1.4 ; \mathrm{df}$ $=4 ; p=0.24)$ between the sediment and sediment + Cassiopea treatments from the core incubations. The organic content was $8.2 \%( \pm 1.9)$ and $11.3 \%( \pm 2.4)$, while the porosity was 0.71 $( \pm 0.12)$ and $0.83( \pm 0.02)$ in the sediment and sediment + Cassiopea treatments, respectively. 


\section{Discussion}

Densities of Cassiopea observed in Codrington Lagoon, Barbuda, are the highest reported values in the literature. In contrast, the mean bell diameters are among the smallest reported (Table 2). A negative relationship between Cassiopea density and bell diameter, as observed in the current study, would seem logical as prey and nutrient availability can become limited. Benthic space could become limited at higher Cassiopea densities but was probably not limited in the current study (benthic coverage 14-18\%). Stoner et al. (2011) suggested that Cassiopea were both more dense and larger in size in an anthropogenically impacted

ecosystem, and the authors argued that this was due to higher nutrient loading. An increase in production could have supported higher prey densities which led to the difference in Cassiopea between the impacted and unimpacted ecosystems. Based on the significant variation in density and size of Cassiopea reported in the literature (Table 2), it would be useful for future studies to report both variables so that benthic coverage can be calculated. Benthic coverage provides a more meaningful variable for making inferences on the ecological impacts of Cassiopea (e.g. Table 1). It also would be informative to have repeated measurements of these variables to document how populations may change over time.

There are likely many other locations with similar or higher densities and/or benthic coverage. Studies documenting new records of Cassiopea invasions do not provide quantitative data, but have included photographs that show extremely high benthic coverage in coastal lakes of New South Wales (Australia; Keable and Ahyong, 2016) and the Itajuru Channel (Cabo Frio, Rio de Janeiro State, Brazil; Morandini et al., 2017). More studies that quantify geographic distribution, density, size, and benthic coverage of Cassiopea are critical to understanding how they may be influenced by climate change, eutrophication, and other anthropogenic stressors.

Empirical (Stoner et al., 2011) and anecdotal (Arai et al., 2001) evidence suggest that Cassiopea abundance is positively related to nutrient loading; however, documenting such a relationship across ecosystems is difficult. Ammonium levels in Pearl Harbor were higher than values previously reported in the coastal waters of Bonaire (Slijkerman et al., 2014), mangrove systems with and without aquaculture impact in New Caledonia (Molnar et al., 2013), and at anthropogenically-impacted sites in the Abaco Islands (Bahamas; Allgeier et al., 2010; Stoner et al., 2011). Nitrogen loading into Codrington Lagoon may originate from groundwater discharge enriched from wastewater. Given high densities of Cassiopea and DIN concentrations at Pearl Harbor relative to published values, the data suggest a relationship between water column DIN and Cassiopea abundance is possible. Stoner et al. (2011) found no relationship between $\mathrm{NH}_{4}^{+}$and Cassiopea density. Instead, the authors noted a positive relationship between density and total phosphorous which suggests that phosphorous was more limited in this system. It is also possible that specific ratios of nutrients (i.e. system stoichiometry), dissolved inorganic nutrients, and nutrient fluxes may all contribute to patterns of Cassiopea density across ecosystems. Labeled nutrient sediment core incubations (e.g. isotopic ammonium; Hoellein et al., 2015) and measurement of nitrogen-isotopic signatures in tissues may be particularly useful to examine the relationship between Cassiopea and nutrient dynamics.

The analysis revealed a clear pattern in which Cassiopea and their algal symbionts changed benthic metabolism from net heterotrophic to net autotrophic. Sediment $\mathrm{O}_{2}$ demand was greater than $\mathrm{O}_{2}$ production in the Pearl Harbor sediment cores, but the presence of Cassiopea increased $\mathrm{O}_{2}$ production $>300 \%$ under light conditions. The survey of Cassiopea found that they cover
$14-18 \%$ of the benthic environment in Pearl Harbor. The calculations (Table 1) with mean benthic coverage of Cassiopea suggest that benthic environment is net autotrophic $\left(1284 \mu \mathrm{mol} \mathrm{O} \mathrm{O}^{-2}\right.$ $\mathrm{h}^{-1}$ ) while the sediment without Cassiopea would be net heterotrophic $\left(-6358 \mu \mathrm{mol} \mathrm{O}_{2} \mathrm{~m}^{-2} \mathrm{~h}^{-1}\right)$. A similar study of Cassiopea in a mangrove lagoon in Queensland, Australia also found much higher rates of $\mathrm{O}_{2}$ production than consumption, which shifted benthic metabolism to autotrophy, with sediment alone net heterotrophic (Welsh et al., 2009). These authors found that light intensity alters the magnitude of the $\mathrm{O}_{2}$ fluxes, where $\mathrm{O}_{2}$ production increases with light intensity until saturation at $\sim 400 \mu \mathrm{E} \mathrm{m}^{-2} \mathrm{~s}^{-1}$ (Welsh et al., 2009). The measurements in Barbuda were performed at mid-day likely under light saturating conditions, thus, future studies should consider patterns of light intensity over a diel cycle when measuring the impact of Cassiopea on benthic metabolism.

Presence of Cassiopea altered benthic nitrogen cycling, with differing effects on $\mathrm{NH}_{4}^{+}$and $\mathrm{NO}_{3}^{-}$. Pearl Harbor sediment had no net flux of $\mathrm{NH}_{4}^{+}$under both light and dark conditions, but sediment + Cassiopea greatly enhanced $\mathrm{NH}_{4}^{+}$uptake. This response was likely due to 1) direct assimilation by Cassiopea and their algal symbionts or 2) effects of Cassiopea on sediment microbial processes. Cnidarians and associated Symbiodinium have the enzymes needed to assimilate $\mathrm{NH}_{4}^{+}$and $\mathrm{NO}_{3}^{-}$directly from the water column, with the majority of uptake by Symbiodinium (Pernice et al., 2012; Radacker et al., 2015). It is also possible that $\mathrm{O}_{2}$ production helped establish oxic conditions needed to enhance nitrification (i.e. bacterial oxidation of $\mathrm{NH}_{4}^{+}$to $\mathrm{NO}_{3}^{-}$), which removes $\mathrm{NH}_{4}^{+}$ from the environment. Welsh et al. (2009) suggested that Cassiopea-mediated photosynthetic $\mathrm{O}_{2}$ production stimulated sediment nitrification, which led to greater $\mathrm{NO}_{3}^{-}$production in an Australian mangrove lagoon. It is also important to note, that Cassiopea may harbor nitrifying bacteria within their tissues or on the surface of their tissues (Welsh et al., 2009; Freeman et al., 2016), as has been found in bivalves (Welsh et al., 2015; Arfken et al., 2017) and other marine invertebrates (Welsh and Castadelli, 2004). Nitrate produced via nitrification may be immediately assimilated or denitrified in this system since there were low water column $\mathrm{NO}_{3}^{-}$concentrations and fluxes. The potential for Cassiopea to affect nitrification requires more careful study to uncover the underlying pathways and mechanisms. Future studies on Cassiopea impacts on benthic nitrogen cycling could use phylogentic (e.g. $16 \mathrm{~S}$ rRNA) and metagenomic techniques to describe microbial community composition and use tracers to follow $\mathrm{NH}_{4}^{+}$from the water column into potential sites of uptake and transformation (Arfken et al., 2017).

The effects of Cassiopea on $\mathrm{NO}_{3}^{-}$flux may be linked to the redox conditions that control nitrification and denitrification. Denitrification (i.e. reduction of nitrate to dinitrogen gas) is an important nitrogen-removal process, particularly in eutrophic ecosystems (Radacker et al., 2015; Zarnoch et al., 2017), and requires organic carbon, anoxia, and $\mathrm{NO}_{3}^{-}$. In our study, $\mathrm{NO}_{3}^{-}$flux was near zero in light conditions, regardless of the presence of Cassiopea; however, in the dark, $\mathrm{NO}_{3}^{-}$flux was greater without Cassiopea. We suggest that intense $\mathrm{O}_{2}$ production by Cassiopea during light conditions promotes sediment nitrification and enhances diffusion of $\mathrm{O}_{2}$ to greater depths in the sediment. This would mean that anaerobic sediments that support denitrifying microbes in Cassiopea-adjacent sediment would be active deeper in the sediment, and may receive less water column $\mathrm{NO}_{3}^{-}$due to greater distance of the diffusion gradient. Conversely, the uptake of $\mathrm{O}_{2}$ by Cassiopea in dark conditions could decrease this diffusion gradient. Understanding this combination of temporal variation in redox conditions, nitrification, denitrification, and sediment profiles driven by Cassiopea's pulsing motion will be essential to predict impacts 
on sediment nitrogen dynamics. Future studies should also perform incubations with Cassiopea alone (i.e. no sediment) to understand how their metabolic activities and interactions with the sediment alter nutrient and gas fluxes.

Environmental context (e.g. sediment characteristics) is critical to document when conducting comparative studies of benthic fluxes in coastal ecosystems (Smyth et al., 2015). For example, Welsh et al. (2009) found Cassiopea to be a source of nitrogen under dark conditions, while our study found Cassiopea to create a greater sink for nitrogen in sediments. Collectively, these data suggest that Cassiopea may promote nitrogen recycling and assimilation, but limit nitrogen removal via denitrification, which could significantly alter nutrient dynamics in subtropical and tropical coastal ecosystems. Thus, effects of Cassiopea could be positive or negative depending on the environmental conditions of the ecosystem. It is important for future studies to clarify the relationship between Cassiopea (and other jellyfish) abundance and nutrient loading to provide a context for interpreting benthic nitrogen fluxes.

Declaration of competing interest

The authors declare that they have no known competing financial interests or personal relationships that could have appeared to influence the work reported in this paper.

Acknowledgements

This project was supported by the Professional Staff Congress at the City University of New York (USA; Award \#66668-00 44). The funding agency had no influence on the research conducted or preparation of this article. We would like to thank John Mussington, Neil "Jala" Gore, and Calvin Gore for extensive discussions on the ecology of Codrington Lagoon. We also appreciate the support of Frank Donnelly at the Baruch College GIS Lab. This manuscript was significantly improved by the comments and suggestions of three anonymous reviewers and the editor. Their efforts were greatly appreciated.

References

Allgeier, J.E., Rosemond, A.D., Mehring, A.S., Layman, C.A., 2010. Synergistic nutrient colimitation across a gradient of ecosystem fragmentation in subtropical mangrove dominated wetlands. Limnol. Oceanogr. 55(6), 2,660-2,668.

APHA, 1998. Standard Methods for the Examination of Water and Waste Water, twentieth ed. American Public Health Assoc, Washington, DC, USA, pp. 413-426.

Arai, M.N., 2001. Pelagic coelenterates and eutrophication: A review. Hydrobiologia 451(13), 69-87.

Arfken, A., Song, B., Bowman, J.S., Piehler, M., 2017. Denitrification potential of the eastern oyster microbiome using a 16S rRNA gene based metabolic inference approach. PLoS One 12(9), e0185071.

Benfield, E.F., 2006. Decomposition of leaf material. In: Hauer, F.R., Lamberti, G.A. (Eds.), Methods in Stream Ecology. Academic Press, San Diego, California, USA, pp. 711-720.

Berner, R.A., 1971. Principles of Chemical Sedimentology. McGraw-Hill, New York, New York, USA.

Boger, R., Perdikaris, S., Potter, A.E., Mussington, J., Murphy, R., Thomas, L., Gore, C., Finch, D., 2014. Water resources and the historic wells of Barbuda: Tradition, heritage and hope for a sustainable future. Island Stud. J. 9 (2), 327-342.

Boger, R., Perdikaris, S., Potter, A.E., Adams, J., 2016. Sustainable resilience in Barbuda: learning from the past and developing strategies for the future. Int. J. Environ. Sustain. 12(4), 1

Brotz, L., Cheung, W.W., Kleisner, K.,Pakhomov, E., Pauly, D., 2012. Increasing jellyfish populations: Trends in large marine ecosystems. Hydrobiologia 690,3-20.

Chelsky, A., Pitt, K.A., Ferguson, A.J., Bennett, W.W., Teasdale, P.R., Welsh, D.T., 2016. Decomposition of jellyfish carrion in situ: Short-term impacts on infauna, benthic nutrient fluxes and sediment redox conditions. Sci. Total Environ. 566, 929-937.

Collado Vides, L., Segura Puertas, L., Merino Ibarra, M., 1988. Observaciones sobre dos escifomedusas del género Cassiopea en la Laguna de Bojórquez, Quintana Roo, México. Rev. Invest. Mar. 9, 21-27.

Condon, R.H., Duarte, C.M., Pitt, K.A., Robinson, K.L., Lucas, C.H., Sutherland, K.R., Mianzan, H.W., Bogeberg, M., Purcell, J.E., Decker, M.B., Uye, S.I., 2013. Recurrent jellyfish blooms are a consequence of global oscillations. Proc. Natl. Acad. Sci. 110(3), 1,000-1,005.

Dong, Z., Liu, D., Keesing, J.K., 2010. Jellyfish blooms in China: dominant species, causes and consequences. Mar. Pollut. Bull. 60(7), 954-963.

Duarte, C., 1990. Seagrass nutrient content. Mar. Ecol. Prog. Ser. 6(2), 201-207.

Duarte, C.M., Pitt, K.A., Lucas, C.H., Purcell, J.E., Uye, S.I., Robinson, K., Brotz, L., Decker M.B., Sutherland, K.R., Malej, A., Madin, L., 2013. Is global ocean sprawla cause of jellyfish blooms? Front. Ecol. Environ. 11(2), 91-97.

Eyre, B.D., Ferguson, A.J., 2005. Benthic metabolism and nitrogen cycling in a subtropical east Australian estuary (Brunswick): temporal variability and controlling factors. Limnol. Oceanogr.50(1), 81-96.

Eyre, B.D., Santos, I.R., Maher, D.T., 2013. Seasonal, daily and diel $\mathrm{N}_{2}$ effluxes in permeable carbonate sediments. Biogeosciences 10(4), 2601-2615.

Freeman, C.J., Stoner, E.W., Easson, C.G., Matterson, K.O., Baker, D.M., 2016. Symbiont carbon and nitrogen assimilation in the Cassiopea Symbiodinium mutualism. Mar. Ecol.Prog. Ser. 544, 281-286.
Gardner, W.S., McCarthy, M.J., An, S., Sobolev, D., Sell, K.S., Brock, D., 2006. Nitrogen fixation and dissimilatory nitratereduction to ammonium (DNRA) support nitrogen dynamics in Texas estuaries. Limnol. Oceanogr. 51(1part2), 558-568.

Hoellein, T.J., Zarnoch, C.B., Grizzle, R.E., 2015. Eastern oyster (Crassostrea virginica) filtration, biodeposition, and sediment nitrogen cycling at two oyster reefs with contrasting water quality in Great Bay Estuary (New Hampshire, USA). Biogeochemistry 122(1), 113129.

Jantzen, C., Wild, C., Rasheed, M., El-Zibdah, M., Richter, C., 2010. Enhanced pore-water nutrient fluxes by the upside-down jellyfish Cassiopea sp. in a Red Sea coral reef. Mar. Ecol. Prog. Ser. 411, 117-125.

Kana, T.M., Darkangelo, C., Hunt, M.D., Oldham, J.B., Bennett, G.E., Cornwell, J.C., 1994. Membrane inlet mass spectrometer for rapid high-precision determination of $\mathrm{N}_{2}, \mathrm{O}_{2}$, and Ar in environmental water samples. Anal. Chem. 66(23), 4166-4170.

Keable, S.J., Ahyong, S.T., 2016. First records of the invasive "upside-down jellyfish," Cassiopea (Cnidaria: scyphozoa: rhizostomeae: Cassiopeidae), from coastal lakes of New South Wales, Australia. Rec. Aust. Mus. 68, 23-30.

McCarthy, M.J., Lavrentyev, P.L., Yang, L., Zhang, L., Chen, Y., Qin, B., Gardner, W.S., 2007. Nitrogen dynamics relative to microbial food web structure in a subtropical, shallow, well-mixed, eutrophic lake (Taihu Lake, China). Hydrobiologia 581, 195-207.

Molnar, N., Welsh, D.T., Marchand, C., Deborde, J., Meziane, T., 2013. Impacts of shrimp farm effluent on water quality, benthic metabolism and N-dynamics in a mangrove forest (New Caledonia). Estuarine. Coast. Shelf Sci. 117, 12-21.

Morandini, A.C., Stampar, S.N., Maronna, M.M., Da Silveira, F.L., 2017. All non-indigenous species were introduced recently? The case study of Cassiopea (Cnidaria: scyphozoa) in Brazilian waters. J. Mar. Biol. Assoc. U. K. 97 (2), 321-328.

Murphy, J., Riley, J.P., 1962. A modified single solution method for the determination of phosphate in natural waters. Anal. Chim. Acta 27,31-36.

Niggl,W., Wild, C., 2010. Spatial distribution of the upside-down jellyfish Cassiopea sp. within fringing coral reef environments of the Northern Red Sea: Implications for its life cycle. Helgol. Mar. Res. 64(4), 281.

Ohdera, A., Abrams, M., Ames, C., Baker, D., Suescún-Bolívar, L., Collins, A., Freeman, C., Gamero-Mora, E., Goulet, T., Hofman, D., Jaimes-Becerra, A., Long, P., Marques, A., Miller, L., Mydlarz, L., Morandini, A., Newkirk, C., Putri, S., Samson, J., Stampar, S., Steinworth, B., Templeman, M., Thomé, P., Vlok, M., Woodley, C., Wong, J., Martindale, M., Fitt, W., Medina, M., 2018. Upside-down but headed in the right direction: review of the highly versatile Cassiopea xamachana system. Front. Ecol. Evol. 6, 35. doi: 10.3389/fevo.2018.00035

Parsons, T.R., Maita, Y., Lalli, C.M., 1984. A Manual of Chemical and Biological Methods for Seawater Analysis. Pergamon Press, New York, New York, USA.

Pernice, M., Meibom, A., Van Den Heuvel, A., Kopp, C., Domart-Coulon, I., HoeghGuldberg, O., Dove, S., 2012. A single-cell view of ammonium assimilation in coral-dinoflagellate symbiosis. ISME J. 6(7), 1314.

Purcell, J.E., Uye, S.I., Lo, W.T., 2007. Anthropogenic causes of jelly fish blooms and their direct consequences for humans: A review. Mar. Ecol. Prog. Ser. 350,153-174.

Rädecker, N., Pogoreutz, C., Voolstra, C.R., Wiedenmann, J., Wild, C., 2015. Nitrogen cycling in corals: The key to understanding holobiont functioning? Trends Microbiol. 23(8), 490497.

Ruttenberg, B., Caselle, J.E., Estep, A.J., Johnson, A.E., Marhaver, K.L., Richter, L.J., Sandin, S.A., Vermeii, M.J., Smith, J.E., Grenda, D., Cannon, A., 2018. Ecological assessment of the marine ecosystems of Barbuda, West Indies: Using rapid scientific assessment to inform ocean zoning and fisheries management. PLoSOne 13(1), e0189355.

Slijkerman, D.M., de León, R., de Vries, P., 2014. A baseline water quality assessment of the coastal reefs of Bonaire, Southern Caribbean. Mar. Pollut. Bull. 86(1-2), 523-529.

Smyth, A.R., Piehler, M.F., Grabowski, J.H., 2015. Habitat context influences nitrogen removal by restored oyster reefs. J. Appl. Ecol. 52(3), 716-725.

Solorzano, L., 1969. Determination of ammonia in natural waters by the phenorhypochlorite method. Limnol. Oceanogr. 14(5), 799-801.

Stoner, E.W., Layman, C.A., Yeager, L.A., Hassett, H.M., 2011. Effects of anthropogenic disturbance on the abundance and size of epibenthic jellyfish Cassiopea spp. Mar. Pollut. Bull. 62(5), 1,109-1,114

Stoner, E.W., Yeager, L.A., Layman, C.A., 2014a. Effects of epibenthic jellyfish, Cassiopea spp., on faunal community composition of Bahamian seagrass beds. Caribbean Nat. 12, 1-10.

Stoner, E.W., Yeager, L.A., Sweatman, J.L., Sebilian, S.S., Layman, C.A., 2014b. Modification of a seagrass community by benthicjellyfish blooms and nutrient enrichment. J. Exp. Mar. Biol. Ecol. 461, 185-192

Stoner, E.W., Sebilian, S.S., Layman, C.A., 2016. Comparison of zooxanthellae densities from upside-down jellyfish, Cassiopea xamachana, across coastal habitats of the Bahamas. Rev. Biol. Mar. Oceanogr.51(1)

US Army Corps of Engineers, 2004. Water resources assessment of Dominica, Antigua, Barbuda, St. Kitts and Nevis. Available at. https://www.sam.usace.army.mil/Portals/46/docs/military/engineering/docs/WRA/N_Caribbean/N\%20CARIBBEAN\%20WRA\%201\%20DEC\%202004.pdf

Welsh, D.T., Castadelli, G., 2004. Bacterial nitrification activity directly associated with isolated benthic marine animals. Mar. Biol. 144(5), 1,029-1,037.

Welsh, D.T., Nizzoli, D., Fano, E.A., Viaroli, P., 2015. Direct contribution of clams (Ruditapes philippinarum) to benthic fluxes, nitrification, denitrification and nitrous oxide emission in a farmed sediment. Estuar. Coast Shelf Sci. 154, 84-93.

Welsh, D.T., Dunn, R.J., Meziane, T., 2009. Oxygen and nutrient dynamics of the upside down jellyfish (Cassiopea sp.) and its influence on benthic nutrient exchanges and primary production. Hydrobiologia 635(1), 351-362.

West, E.J., Welsh, D.T., Pitt, K.A., 2009. Influence of decomposing jellyfish on the sediment oxygen demand and nutrient dynamics. Hydrobiologia 616,151-160.

Zarnoch, C.B., Hoellein, T.J., Furman, B.T., Peterson, B.J., 2017. Eelgrass meadows, Zostera marina $(\mathrm{L}$.), facilitate the ecosystem service of nitrogen removal during simulated nutrient pulses in Shinnecock Bay, New York, New York, USA. Mar. Pollut. Bull. 124(1), 376-387. 